\title{
THE ROLE OF SOCIAL MEDIA IN CORPORATE REPUTATION MANAGEMENT - THE RESULTS OF THE POLISH ENTERPRISES
}

\author{
Danuta SZWAJCA \\ Silesian University of Technology, Faculty of Organization and Management, Gliwice, Poland \\ e-mail: danuta.szwajca@polsl.pl
}

\begin{abstract}
The exponential growth of the Internet and social media (SM) in the recent years has contributed to changing the communication environment in which stakeholders as their users may post and distribute their opinions about the company and its products. This generates a number of potential threats to the image and reputation of both people and organizations. Companies cannot ignore this fact and should use SM not only as an additional communication marketing channel but also in a broader context - as a tool to build and protect their reputation. This article aims to identify the extent and directions of the use of SM in the activities of companies operating on the Polish market in the area of reputation management. The results of research showed that Polish companies recognize the potential of SM and try to apply them in their marketing efforts. In the approach to the SM as a communication channel, the traditional way of thinking dominates, in which they are treated as just another promotional tool used by two departments: marketing and public relations (PR). This way of using SM is not integrated and does not allow effective building and protecting reputation in the Internet environment. To achieve this goal, the following research methods were used: critical analysis of literature and analysis of secondary sources in a form of report from the research conducted by various national and foreign research centers.
\end{abstract}

Keywords: corporate reputation, reputation management, corporate communication, social media.

\section{$1 \quad$ Introduction}

Social media (SM) is a new, dynamically developing channel of interpersonal communication that becomes a serious challenge for managers in corporate reputation management (Lariscy, et al., 2009). Thanks to its specific features (i.e., interactivity, mass-character, speed, global range, and so on), this type of media may constitute both opportunity and threat for reputation building and protection.

On the one hand, they may be used as a great tool to create the desired image and reputation because of the possibility of building interactive relationships with an unlimited number of recipients, who may be not only customers but also stakeholder groups: employees, investors, and business partners (Yang and Lim, 2009; Etter, 2013).

On the other hand, their functioning, remaining beyond the company's control and influence, generates serious threats to reputation. One negative submission or comment in the Internet about the company or product may launch an unstoppable avalanche that may damage the carefully created image and destroy the reputation that had been built for years. Besides, the use of blogosphere is connected with a danger of revealing or leaking confidential data, violating author's rights, and so on ( $\mathrm{Li}$ and Bernoff, 2011, pp.56-57).

Practice shows that so far, the latter side of SM, unfavorable for the company, seems to have taken over. In these media, the image crises of companies and products, hacker attacks, data leaks and so on are echoed widely but not the success of creating the desired reputation. Here some examples from Polish market may be given. The first one is related to Adidas company that at the beginning of 2011 painted out popular graffiti masterpieces in one of Warsaw's residential districts in order to place its own advertisements there. It triggered a rapid reaction of the fans of this type of art on Facebook. These protests were supported by 20,000 young people who in one day decided that wearing Adidas clothes is out of fashion.

The company, afraid of consumer boycott, admitted its mistake, apologized, and gave the wall back to the artists (www 1, 2011). Another example concerns 
the unfortunate commercial by Play mobile phone operator, where they encouraged to buy the SIM card using an argument that it may be as easily disposed as a dog given to a shelter. Animal lovers and animal right activists made a quick response. The company reacted fast organizing an event of donating dog food to all shelters in the whole Poland, what allowed transferring the failure into the image success(www 2, 2010).

The amount of SM users is gradually increasing at the pace of $20 \%$ yearly. It is estimated that until the year 2017, it will rise to 2.55 billion users (www 3,2013 ). More than $72 \%$ of internauts regularly uses SM; furthermore, the US and UK residents spend 13 and 16 minutes per hour accordingly on SM (www 4, 2014). In the face of such huge popularity and commonness of SM in the process of interpersonal communication, the companies can no longer underestimate or ignore them but should include them in strategic programs and plans.

According to Argenti (2011, pp.61-64), the use of SM by companies becomes a necessity and opportunity for growth. However, in order to gain success, it is not enough to use them passively and occasionally they need to be used strategically as one of the basic instruments of marketing communication.

The objective of the paper is to identify the scale, range, and directions of using SM in the activity of companies operating on the Polish market in the context of reputation building and protection.

In order to achieve the objective, the following research methods were used: critical literature review and analysis of secondary sources in a form of research reports conducted by various science and research centers (among others, Harvard Business Review Polska together with Capgemini Polska, Connect, Deloitte).

\section{The areas of using social media in company activity}

SM are defined as a group of applications basing on the ideology and technique of Web 2.0, enabling the creation and exchange of contents by users (Kaplan, Haenlain, 2010). Thanks to the appearance of new Internet generation "Web 2.0", their emergence and development made an interactive communication between people possible (McAfee, 2009; Solis, 2011, pp.1; Królewski and Sala, 2014, pp.7778). SM encompass various websites that allow sending texts, photos, videos, opinion exchange, commenting current news and so on. One of the most popular websites is Facebook, which is established in 2004 (in 2014, it had 1.28 billion active users), that enables creating groups and networks, exchanging information and photos, as well using applications accessible on the platform.

Table 1. Social media classification according to the main area of their utilization in the company (source: own work based on: Buchnowska, 2013; Kaznowski, 2010)

\begin{tabular}{|l|l|l|l|}
\hline \multicolumn{1}{|c|}{ Type of portal } & Main areas of utilization & Character of utilization & \multicolumn{1}{|c|}{ SM examples } \\
\hline Social network (friends) & $\begin{array}{l}\text { PR, marketing, sales, } \\
\text { customer service, CSR, } \\
\text { R\&D }\end{array}$ & $\begin{array}{l}\text { Relationship building } \\
\text { and retaining }\end{array}$ & $\begin{array}{l}\text { Facebook, Google+, } \\
\text { nk.pl, mySpace }\end{array}$ \\
\cline { 2 - 4 } Social network (business) & $\begin{array}{l}\text { Human resources man- } \\
\text { agement, PR, R\&D }\end{array}$ & LinkedIn, GoldenLine \\
\hline Video network & PR, marketing, sales & \multirow{2}{*}{ Co-sharing } & You Tube, Dailymotion \\
\cline { 5 - 5 } Photo network & PR, marketing, sales & $\begin{array}{l}\text { Pinterest, Instagram, } \\
\text { Flickr, Picasaweb }\end{array}$ \\
\hline Microblog & PR, marketing, CSR & $\begin{array}{l}\text { Instant informing and } \\
\text { commenting news }\end{array}$ & Twitter, Blip, Tumblr \\
\hline
\end{tabular}


Table 1. Social media classification according to the main area of their utilization in the company, cont. (source: own work based on: Buchnowska, 2013; Kaznowski, 2010)

\begin{tabular}{|c|c|c|c|}
\hline Type of portal & Main areas of utilization & Character of utilization & SM examples \\
\hline Blog & PR, marketing, CSR & \multirow{2}{*}{$\begin{array}{l}\text { Content publication } \\
\text { (opinions and views) }\end{array}$} & $\begin{array}{l}\text { wordpress.com, blogger, } \\
\text { blogspot, blox }\end{array}$ \\
\hline Wiki & $\begin{array}{l}\text { Information and } \\
\text { knowledge management, } \\
\text { R\&D, customer service }\end{array}$ & & Wikipedia, mfiles \\
\hline Group shopping & Sales, marketing & Product sales & $\begin{array}{l}\text { Groupon, Gruper, } \\
\text { CITEAM, FastDeal }\end{array}$ \\
\hline Crowdsourcing & $\begin{array}{l}\text { R\&D, PR, marketing, } \\
\text { CSR }\end{array}$ & $\begin{array}{l}\text { Co-creation and coopera- } \\
\text { tion }\end{array}$ & $\begin{array}{l}\text { Ideabrewery, My Star- } \\
\text { bucks Idea, Bank of Ideas } \\
\text { BZ WBK }\end{array}$ \\
\hline Geolocation & PR, marketing, sales & $\begin{array}{l}\text { Information exchange } \\
\text { about the place }\end{array}$ & $\begin{array}{l}\text { Foursquare, Facebook } \\
\text { Places }\end{array}$ \\
\hline
\end{tabular}

The range of possibilities and utilization of SM by the company is very wide. It not only encompasses the marketing and public relations (PR) sphere but also areas such as sales, customer service, human resources management, research and development (R\&D), or corporate social responsibility (CSR). Table 1 shows the types of SM with the indication of the area of their utilization in the company. As one may see, SM mostly serve relationship building and retaining with different groups of users through information, views, and comments exchange. Because of that the company using SM may be aimed at the following objectives:
- company/brand image creation and dissemination,

- building customer and other stakeholder groups relationships,

- advertising and sales of products and services,

- employee recruitment,

- knowledge and new ideas gaining.

SM are mostly a new tool and channel of internal communication - company management with employees and among employees - and also external one - with external company stakeholders (Table 2).

Table 2. Review of SM utilization in internal and external communication (source: Szczepańczyk M., 2013, pp.191-192)

\begin{tabular}{|c|l|c|}
\hline Social media & \multicolumn{1}{|c|}{ Utilization in internal communication } & Utilization in external communication \\
\hline \multirow{3}{*}{ Wiki } & $\begin{array}{l}\text { - group work } \\
- \text { publishing information for employees } \\
- \text { project management } \\
- \text { documentation creation } \\
- \text { online support }\end{array}$ & $\begin{array}{l}\text { - allowing the customers to add product de- } \\
\text { scriptions, possibilities of their use, and bene- } \\
\text { fits from their use }\end{array}$ \\
\hline
\end{tabular}


Table 2. Review of SM utilization in internal and external communication, cont.

(source: Szczepańczyk M., 2013, pp.191-192)

\begin{tabular}{|c|c|c|}
\hline Social media & Utilization in internal communication & Utilization in external communication \\
\hline Blog & $\begin{array}{l}\text { - ideas generation and their verification } \\
\text { - triggering employee engagement and } \\
\text { development of their mutual contacts } \\
\text { - teams and project groups communica- } \\
\text { tion with the whole company, inside } \\
\text { the team, and during project realiza- } \\
\text { tion }\end{array}$ & $\begin{array}{l}\text { - following customer submissions and com- } \\
\text { ments } \\
\text { - possibility of adding comments by the most } \\
\text { loyal customers } \\
\text { - possibility of mutual commenting by employ- } \\
\text { ee and selected customer, for example, tester } \\
\text { - possibility of following the so-called social } \\
\text { echo and reacting to received feedback }\end{array}$ \\
\hline RSS/Atom & $\begin{array}{l}\text { - subscribing to RSS/Atom channels } \\
\text { important to employees, providing } \\
\text { access to most current information }\end{array}$ & $\begin{array}{l}\text { - customer subscription } \\
\text { - building customer base } \\
\text { - distribution of selected information to the } \\
\text { particular groups of subscribed customers }\end{array}$ \\
\hline Mashup & $\begin{array}{l}\text { - specialized for business needs enables } \\
\text { linking various kinds of business in- } \\
\text { formation } \\
\text { - data processing and presenting in a } \\
\text { particular way }\end{array}$ & $\begin{array}{l}\text { - enabling presenting and processing various } \\
\text { kinds of information that may be personalized } \\
\text { according to customer needs, message recipi- } \\
\text { ent }\end{array}$ \\
\hline $\begin{array}{l}\text { File, audio, video } \\
\text { multimedia, doc- } \\
\text { ument exchange, } \\
\text { and co-sharing } \\
\text { networks }\end{array}$ & $\begin{array}{l}\text { - sharing multimedia files } \\
\text { - participation in online courses } \\
\text { - opinion exchange about the contents } \\
\text { published, assessment of their quality, } \\
\text { and usability for the company }\end{array}$ & $\begin{array}{l}\text { - making files, samples, testers accessible } \\
\text { for customers } \\
\text { - making specialized data accessible for the } \\
\text { particular expert groups, for example, texture } \\
\text { of decorative material to be used in internal } \\
\text { design programs }\end{array}$ \\
\hline Social networks & $\begin{array}{l}\text { - company communication platforms } \\
\text { - building project groups } \\
\text { - employee profiles management } \\
\text { - contact with business partners }\end{array}$ & $\begin{array}{l}\text { - establishing company fanpage } \\
\text { - establishing company profiles on social plat- } \\
\text { forms } \\
\text { - possibility of interacting with users of social } \\
\text { networks } \\
\text { - running promotional and charity events }\end{array}$ \\
\hline
\end{tabular}

However, it should be emphasized that communication using SM is fundamentally different from the communication using traditional media, when the company was able to direct a well-prepared and planned message to a group of isolated recipients. SM create a new communication environment where it is not enough to speak but now one must talk, it is not enough to communicate, one must listen, it is not enough to show, one must get engaged now and, in addition, take care of everyone separately (instead of speaking to everyone at once) and be verified 24/7 (Niemedyński, 2010).

\section{Justification of the need to use SM in repu- tation management}

As it was stated earlier, SM are a new, very effective tool for communicating with various groups of stakeholders; therefore, they can be used to create a desired image and to build the reputation of the company. The specificity and the advantage of new media in the context of building reputations is the fact that they can allow establishing of close relationships with the engaged groups of recipients; creation of such group forces transparency and requires an open, honest dialogue that gives the chance 
to achieve greater trust from the stakeholders. Internet media also become more and more trusted.

According to the research conducted in 20 countries of the world (Edelman Trust Barometer, 2015), the confidence in online search engines increased from $62 \%$ in year 2012 to $64 \%$ in year 2015 and in SM from 45\% in year 2012 to $48 \%$ in year 2015 . On the other hand, the level of confidence in traditional media is decreasing: from $67 \%$ in year 2012 to $62 \%$ in year 2015 .

An important argument justifying the need for using SM in reputation management of contemporary organizations is the generational change. Currently, people born between years 1980 and 1995 are entering the labor market - these are the years that are described as the generation $\mathrm{Y}$. The main criterion for distinguishing this generation is proficiency at skills of using modern information and telecommunication technologies: the Internet, mobile telephones, and digital devices (Czekańska-Mirek, 2011, p.163). The lifestyle of people representing this generation indicates that SM will be an indispensable tool for establishing all forms of relationships with them. The lifestyle of representatives of generation Y is characterized by (Filiciak, et al., 2010):

- a wish to keep in touch permanently with the reference group,

- a wish for individualization, distinguishing oneself through the presentation of one's thoughts, emotions, and mood,

- a wish to maintain work-life balance,

- shifting the border of privacy (in comparison with the previous generation),

- a negative attitude toward mass, not personalized advertising,

- being used to acting quickly and receiving instant feedback,

- co-sharing digital content (viral marketing).

Apart from that, they are characterized by resistance to advertising messages and a low level of loyalty toward a brand or company. It turns out that young people from generation $\mathrm{Y}$ are not willing to defend the reputation of an enterprise on a corporate profile. This was showed by the results of research conducted in this area (Moroz, 2013, pp.123-131). Only 20\% of the respondents replied that they will uncondition- ally defend the company in a discussion. On the other hand, a definite majority declared that they will not defend the company in a discussion because they believe that:

- the company has a person responsible for communication on the fanpage (86.9\%),

- the company does not have to respond to every attack (83.3\%),

- one should publicize the company's faults when it comes to their offer and service (79.2\%).

Utilization of SM is necessary and justified not only in the context of creating the desired reputation but also in the context of protecting it from new threats. It turns out that the development of modern media caused the multiplication of reputation risk. According to Weber Shandwick's research (2009), reputation is currently considered by managers to be one of the most sensitive resources, exposed to unexpected attacks through Internet tools.

The environment of modern media creates the potential for the creation of serious and strong opinionforming centers in the net, which can disseminate both positive as well as negative information about the company. One negative comment from a dissatisfied customer or one untrue rumor is enough to launch a whole avalanche of negative comments. In order to protect the reputation of the company from such attacks and their consequences, an immediate response on the same channel is necessary. It requires a constant presence in media, their ongoing monitoring, and implementation of the mechanisms for reacting quickly.

In this place, it is worth emphasizing that the usefulness of modern media is very significant in managing every crisis situation, not only one caused by a negative, untrue comment but also one caused by a mistake, error, violation of the law or ethical rules, or a random event (Szwajca, 2013). In each case, the effectiveness of crisis management process is, to a great extent, determined by an open, efficient, and sincere communication (Gonzáles-Herrero and Smith, 2008; Mei, Bansal and Pang, 2010).

In the first stage, the reaction time and quick transfer of the most important information counts, given in a synthetic and comprehensible way in order 
to prevent various speculations and conjectures, which usually negatively influence reputation.

In the following stages, SM can be used to inform those groups of stakeholders that have been most affected by the crisis about the steps and corrective actions taken by the company.

Companies are beginning to use SM more and more commonly in their business activities. The cyclical research conducted among the enterprises from the Fortune 500 list show that as much as 91\% of them use at least one SM type: most often You Tube, then Twitter, and Facebook (Distaso and McCorkindale, 2013). In case of Polish companies, this interest is still low. Data from the European Commission show that in year 2015, in Poland, 8.4\% of companies were present in SM. In comparison to year 2014,there is an increase but a slight one. This result gives Poland the penultimate position in the European Union. The average for 28 countries is $18 \%$ (www 5,2016 ).

It is particularly alarming considering the increasing popularity of the Internet and SM among Poles. Among 26 million Internet users in Poland, $74 \%$ connects to the global network at least once per day, $20 \%$ once per week, $5 \%$ once per month, and only $1 \%$ does it less often than once in a month. Out of that $48 \%$ of the traffic comes from people using Internet on a laptop or a desktop PC (a decrease of $10 \%$ in comparison to January 2015) and $51 \%$ of the traffic is generated by smartphones (increase by 14\%). An active Facebook account is already owned by 14 million people $-36 \%$ of the total population of Poland (www 6, 2016).

Taking into consideration the numbers and development trends in this area, it should be stated that the digital potential is not being fully used by the companies.

\section{The use of SM by Polish companies - according to survey research}

The research concerning the use of SM by enterprises is usually a survey research conducted among various employee groups. The examples of such research in relation to Polish companies are:
- "Social Enterprise 2012" study conducted in the year 2012 by the researchConnect company on a representative sample of 200 large and medium enterprises - the respondents were employees from various departments,

- “Biznes społecznościowy 2012" study conducted by the Deloitte company in the year 2012 on a sample of 71 companies from several branches of industry - the respondents were marketing specialists,

- "Polskie firmy w mediach społecznościowych" study conducted in the year 2011 by HBR Polska together with Capgemini consulting company on a sample of 22 companies - the respondents were the managers of marketing and communications departments.

The first two studies contain quantitative data about the level to which SM is used by Polish companies can be compared with companies from other highly developed countries, that is, the United States, the United Kingdom, Canada, and Australia (Table 3).

As it can be seen in the table, Polish companies use mainly two portals: Facebook and You Tube. The high discrepancy in the results of Connect and Deloitte is justified by the dissimilarity of the respondents' groups. A much lower percentage in the Connect study stems from the fact that the communication via SM is done mostly by marketing and communications specialists and, therefore, the employees from other departments do not know that the company uses SM at all.

Taking into consideration the Deloitte results, it can be stated that the level of utilization of SM by Polish companies in comparison to the companies from other countries of the world (the United States, the United Kingdom, Canada, Australia) is low. It is particularly true regarding Twitter, LinkedIn, and own blog networks. In photo or geolocation networks (i.e., Pinterest, Foursquare), Polish companies are not present at all.

Analyzing these studies from the point of view of creating and protecting reputation, one can quote the results regarding the goal of the presence in SM, groups of recipients, published content, monitoring, and crisis situations. 
Table 3. The use of SM by Polish companies in comparison with the companies from selected countries of the world

(source: Developed based on: Connect, 2012; Deloitte, 2012; SocialMediaExaminer, 2013)

\begin{tabular}{|l|c|c|c|}
\hline \multirow{2}{*}{ Area of study } & \multicolumn{2}{c|}{ Poland } & $\begin{array}{c}\text { ine United States, the United } \\
\text { Kingdom, Canada, Australia }\end{array}$ \\
\hline \multicolumn{1}{|c|}{ Source } & Connect 2012 & Deloitte 2012 & SocialMediaExaminer 2013 \\
\hline \multicolumn{1}{|c|}{ Name of the portal } & Percentage of the examined companies present on the given portal \\
\hline Facebook & 35 & 86 & 92 \\
\hline You Tube & 15 & 38 & 56 \\
\hline Twitter & 7 & 18 & 80 \\
\hline Google+ & 6 & 23 & 42 \\
\hline GoldenLine & 3 & 20 & - \\
\hline Nk & 3 & 10 & - \\
\hline LinkedIn & 2 & 30 & 70 \\
\hline Own blog & 2 & 15 & 41 \\
\hline Pinterest & - & - & 11 \\
\hline Foursquare & - & - & Marketing specialists \\
\hline Examined & Employees & & \\
\hline
\end{tabular}

The main goals of the presence in SM are:

- following trends visible on the market/in competition $-62 \%$,

- positive influence on the brand perception $-59 \%$,

- gaining knowledge about the present and potential customers $-35 \%$,

- increase in sales $-25 \%$.

When it comes to the target groups of recipients, these are mainly current and potential customers (respectively, $75 \%$ and $82 \%$ ), current and potential employees (respectively, 34\% and 39\%), and business partners. The most often published content is competitions $(75 \%)$, then multimedia (65\%), applications $(37 \%)$, and loyalty programs $(10 \%)$.

Most companies (58\%) monitor only the contents and comments on their profiles and browse the Internet on their own in the search for information about the company (48\%). Almost $60 \%$ of the surveyed companies have not had to cope with a crisis situation in SM yet; therefore, only a small percentage of them prepares scenarios in case of any threat to the reputation. Almost half of those surveyed does not conduct any training for employees in regards to publishing content in SM.

The results presented speak about underestimating SM and small utilization of their potential in the area of creating permanent, deepened relationships of Polish enterprises with various groups of stakeholders, not only with the customers. SM are used in a passive way, more as a tool for sales promotion or advertising than as an instrument of creating permanent, open relationships with the recipients.

Entries and comments about the company are not monitored systematically, as a result of which potential attacks from Internet users cannot be identified on time. There is also a lack of proper tools and procedures enabling a suitably fast reaction to crisis situations. Polish managers are not fully aware of the possibilities granted by an active presence in the net and by the creation of planned marketing strategies with the use of SM.

In the Capgemini research, based on in-depth interviews with the managers and communications departments, The Social Media Utilization Maturity Model-SM was used, in which the maturity degree 
is assessed in a five-point scale (Sumara, et al., 2012). Twenty-two large companies from the sectors of finance, TMI (telecommunication, media, and Internet), FMCG (fast moving consumer goods), and energy and automotive industry took part in the research. These enterprises are the leaders in their respective sectors when it comes to using SM. The research covered the following areas:

1) the awareness of the organization regarding SM and the ways of their utilization in the activity of the company,

2) the level of employee preparation for the actions in the area of SM,

3) the way in which SM is incorporated into business processes,

4) the level of integrating tasks and responsibility of particular department in the course of the realization of the SM strategy,

5) the actual utilization of SM in the activities of the company,

6) the way of acquiring and processing information coming from SM,

7) the vision, extent, and utility of IT tools supporting the company in the actions in the area of SM.
According to the achieved results, the average level of maturity of all branches of industry was evaluated to be on the level of 2.5-3 points, wherein the highest level (a bit above 3 points) was noted in the first area (awareness of the companies regarding the ways of utilizing SM), while the lowest (less than 2 points) in the fourth (the level of integration of SM with processes and strategy) and seventh areas (the extent of IT tools supporting actions in SM).

The best score across all categories was received by TMI and FMCG companies, while the worst by energy and automotive industries. In the majority of the examined companies, SM are used for the promotion of products and services and for branding activities. The most popular services are Facebook and YouTube. Marketing and PR departments are responsible for the communication via SM, where special posts are created to handle the services.

Many companies also use the services of external agencies in the form of outsourcing. The employees of other departments are neither engaged in these actions nor trained in the area of handling SM. Consequently, it can be seen that the enterprises have only a single point of contact with the communities; SM are not integrated with the operational processes but operate as hermetic organizational silos (Fig. 1).
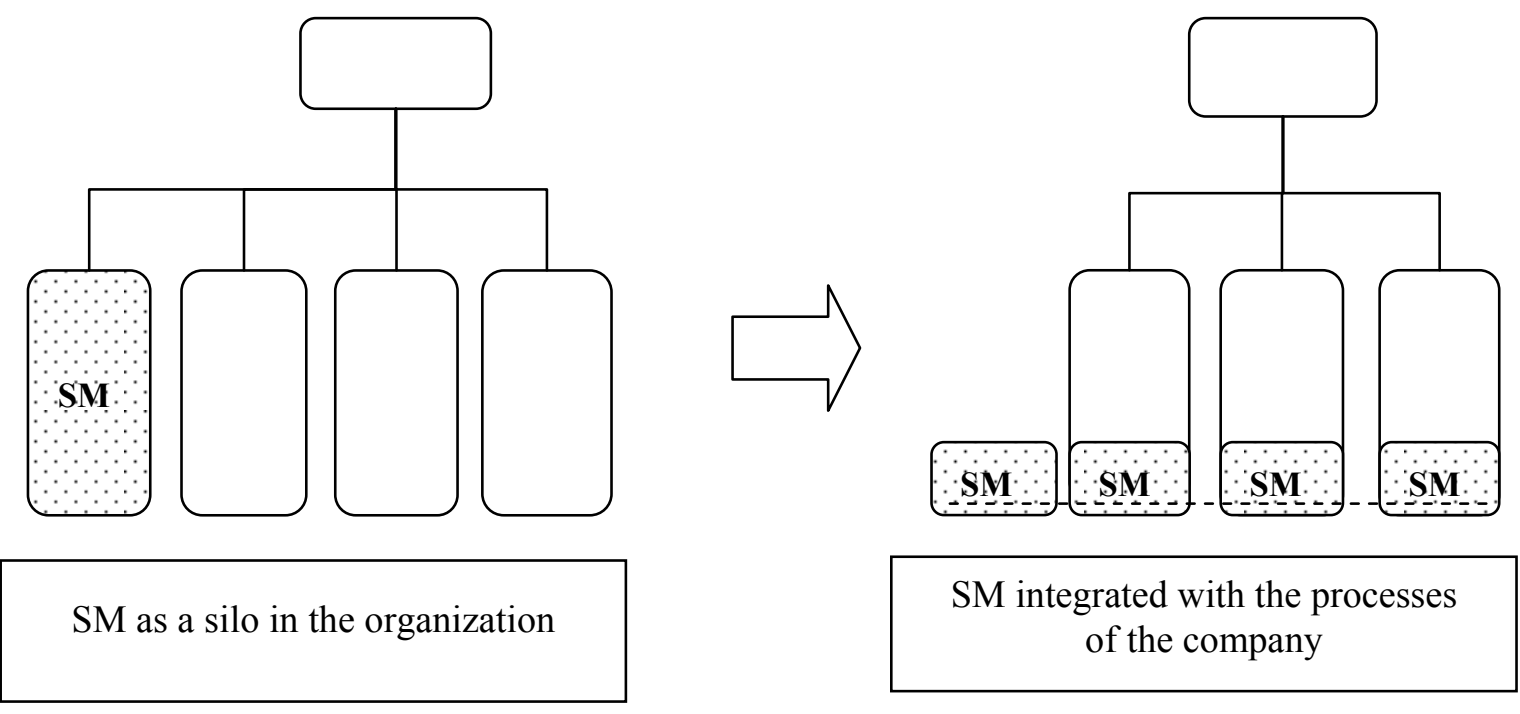

Figure 1. Silo approach to SM (source: Sumara, et al., 2012) 
Only few among the examined companies monitor SM from the point of view of threats to reputation. Most often they are based on the reports of external agencies; there is a lack of automatic online alerts. Therefore, it is hard to expect a quick reaction from the service employees to customers' complaints expressed on social portals. In practice, the reactions to crisis situations are delayed and the answers to difficult questions appear too late, when negative comments have already spread in the net.

Summarizing the results of this research, it may be stated that although the majority of the surveyed companies perceive the significance and potential of SM, it is not used in practice.

\section{SM utilization by Polish companies - according to the analysis of secondary sources}

The survey research concerning the assessment of the scale of SM utilization by Polish companies is based on the knowledge of various employee groups that is differed and not complete. Therefore, the re- sults obtained are not fully reliable and credible. Internet services and official business profiles in social networks are another source of information on that matter. A method of these sources exploration and analysis was used by Buchnowska (2013) in her research. The research sample encompassed 100 largest Polish enterprises in terms of revenues, from the report of List 500 by "Polityka" as for 2012. This report included the companies from three sectors: light and heavy industry, services, and trade (excluding the financial sector that was put in a separate report). The analysis was performed in two steps:

1) visiting business platform of each company and searching for links to social networks, what allowed including only official profiles of company/brand,

2) visiting all identified profiles in SM in order to determine whether they are updated and active, whether they are integrated, and how much the companies and fans are involved.

Table 4. Popularity of particular types of SM

(source: Buchnowska 2013, p.61)

\begin{tabular}{|c|c|c|c|}
\hline Type of network & Name of network & \multicolumn{2}{|c|}{$\begin{array}{c}\text { Percentage of companies present } \\
\text { in SM }\end{array}$} \\
\hline \multirow{3}{*}{ Social network } & Facebook & 79 & \multirow{3}{*}{83} \\
\hline & Google + & 13 & \\
\hline & $\mathrm{Nk}$ & 6 & \\
\hline \multirow{2}{*}{ Video network } & You Tube & 58 & \multirow{2}{*}{58} \\
\hline & Dailymotion & 4 & \\
\hline \multirow{2}{*}{ Business network } & LinkedIn & 17 & \multirow{2}{*}{19} \\
\hline & GoldenLine & 4 & \\
\hline \multirow{2}{*}{ Microblog } & Twitter & 19 & \multirow{2}{*}{19} \\
\hline & Blip & 4 & \\
\hline Company blog & Blog & 15 & 15 \\
\hline \multirow{3}{*}{ Photo network } & Pinterest & 9 & \multirow{3}{*}{13} \\
\hline & Instagram & 4 & \\
\hline & Flickr & 2 & \\
\hline Geolocation network & Foursquare & 8 & 8 \\
\hline
\end{tabular}


According to the analysis performed, it was found that $53 \%$ of companies has an account in at least one social network. The greatest part of the examined enterprises (34\%) present in SM has official profiles on one portal and not many fewer of them $(30 \%)$ has profiles on three different portals. All in all, 66\% of companies present in SM possess a profile on more than one portal and $49 \%$ of them have profiles on at least three portals.

The most popular social networks are those of friends' character among the examined enterprises. About $83 \%$ of companies present in SM use them, and Facebook is used the most $-79 \%$ of companies present in SM has an account there (Table 4).
The second most popular type of media are video networks, You Tube in particular. About 58\% of companies present in SM use it. The remaining types of networks are used in a much less scale, especially geolocation and photo networks.

The research showed that the scale and type of social networks used by the largest Polish enterprises depend, to a great extent, on the industry that the company belongs to. The examined enterprises represent 16 branches of industries, and the most popular are food industry, mineral resources, fuel, and trade. Table 5 shows the activity of particular industry in SM.

Table 5. The presence of examined enterprises in SM according to the industry (source: Buchnowska, 2013, p.64)

\begin{tabular}{|c|c|c|c|}
\hline \multirow[b]{2}{*}{ Industry } & \multicolumn{2}{|c|}{ Number of enterprises } & \multirow{2}{*}{$\begin{array}{l}\text { Number of portals } \\
\text { (total/average per industry) }\end{array}$} \\
\hline & Total & $\begin{array}{c}\text { Possessing } \\
\text { a portal }\end{array}$ & \\
\hline Clothing and footwear industry & 1 & $1 / 100 \%$ & $5 / 5$ \\
\hline Military industry & 1 & $1 / 100 \%$ & $3 / 3 /$ \\
\hline Transport and logistics & 3 & $3 / 100 \%$ & $8 / 2.7$ \\
\hline Entertainment & 3 & $3 / 100 \%$ & $6 / 2$ \\
\hline Electronic industry & 10 & $8 / 80 \%$ & $23 / 2.3$ \\
\hline Trade & 13 & $10 / 77 \%$ & $17 / 1.3$ \\
\hline Car industry & 6 & $4 / 67 \%$ & $11 / 1.8$ \\
\hline Food industry & 15 & $9 / 60 \%$ & $18 / 1.2$ \\
\hline Telecommunication and IT & 7 & $4 / 57 \%$ & $16 / 2.3$ \\
\hline Pharmaceutics and cosmetics & 5 & $2 / 40 \%$ & $2 / 0.4$ \\
\hline Mineral resources and fuel & 14 & $5 / 36 \%$ & $12 / 0.9$ \\
\hline Heat and power industry & 7 & $2 / 29 \%$ & $5 / 0.7$ \\
\hline Chemical industry & 6 & $1 / 17 \%$ & $3 / 0.5$ \\
\hline Construction industry & 6 & 0 & 0 \\
\hline Metal industry & 2 & 0 & 0 \\
\hline Wood and paper industry & 1 & 0 & 0 \\
\hline Total & 100 & $53 / 53 \%$ & $129 / 1.3$ \\
\hline
\end{tabular}


As one may notice, each of the enterprises representing clothing and footwear, military industry, transport and logistics, as well as entertainment possesses an account on at least one social network, and most of them (seven out of eight companies) on at least two. The most active according to the number of portals are the enterprises from clothing and footwear industry.

It is worth noticing that a specific activity in SM of those industries does not only concern the largest companies but all of them. It turns out that the companies and brands connected with fashion are very popular among the SM users, especially Facebook. Clothing is the second (after music) industry in terms of the number of fans and fourth one in terms of users involved (after e-commerce, sport, and music) on Facebook (Buchnowska, 2013, p.65 following: Sotrender, 2012).

The enterprises from three industries are totally absent in SM: construction, metal and wood, and paper industries. When talking about construction industry, the reason for not using SM may be a fact that according to ASM company report, opinions expressed in the network about construction brands, products, and services are not particularly important for the experts from this industry, that is, contractors, investors, and architects (Buchnowska, 2013, p.66 following: ASM 2013). However, little interest in SM among the companies from metal and wood and paper industries may come from the specificity of recipients who are institutional customers. Social networks, especially for friends, mainly serve for establishing contacts with consumers and individual customers; thus they are more often used by the companies performing in business-tocustomer (B2C) model than business-to-business (B2B) model.

Both methods, that is, in-depth interviews with employees responsible for SM management and analysis of social networks and websites, were used in research on brewing industry that is carried out in the year 2014 (Szamrowski and Pawlewicz, 2015). The research sample encompassed 37 companies, including breweries belonging to the largest brewing corporations in Poland and regional breweries, varied in terms of size.
According to the research results, only $25 \%$ of examined breweries does not use SM in their PR activities. It mainly concerns small regional breweries. All breweries belonging to brewing corporations use at least one social media. These are mostly Facebook, You Tube, and LinkedIn, and rarely Twitter. A great share of brands that are a part of capital groups possess their own SM channels for communication with the environment; however, the examined employees think that some platforms within the frames of a particular group are not integrated enough. Among the group of small and medium regional breweries, the use of SM is much lower $86 \%$ of them use only one channel (it is Facebook).

SM are used by the examined breweries mainly for product promotion ( $82 \%$ of indications) and for establishing dialogue with the users society of a given platform $(81 \%)$. Only a bit more than $40 \%$ of examined companies ( $80 \%$ in case of the largest ones) runs effectiveness monitoring of SM utilization; nevertheless, its frequency was quite varied in most cases. Therefore, it may be assumed that it was of chaotic character.

With regards to the companies that do not use SM, the main barriers were indicated as a lack of time and a lack of properly qualified employees.

\section{Summary}

A dynamic development and increasing popularity of SM in the past decade triggered a growing interest in this communication channel in business environment. The companies in the most developed countries more and more often use the Internet and SM as an important channel of marketing communication and they develop online marketing strategies. SM, thanks to their specific features (such as interactivity, mass-character, global range, availability), are particularly useful when establishing relationships and active dialogue with different stakeholder groups. For this reason, they constitute a new, important tool for building and protecting corporate reputation.

Polish companies also start to appreciate the potential and see the need to use SM in their activity; however, in practice, the scale and range of their utilization is rather small. The research results mentioned in the paper are a proof for that. 
Most Polish companies use only social networks (mainly Facebook) and video ones (You Tube), disregarding the possibilities of using other tools such as geolocation, photo networks, and company blogs. SM are used similarly to traditional media as they mainly serve for product and service promotion and for running image actions. Thus, they are considered to be an additional marketing communication channel and not a self-contained tool to create new ways of activity or new business models. In companies, SM management is carried out by specialized units, employees of marketing or PR department, or external agencies; therefore, the contact with societies is of one-way type. A silos approach to SM dominates, where they are neither integrated with operating processes in the whole organization nor coordinated in a form of one coherent strategy.

Despite very large significance of SM in the process of building and protecting reputation from various threats, Polish companies do not show a sufficient activity in this area. Relationships, using SM, are only established with customer, rarely with employees, business partners, or other stakeholder groups. These contact are rather of one-way, passive character and mainly serve sales purposes. Consequently, SM are used as a sales promotion or marketing tool and not as an instrument of building permanent, open relationships with stakeholders that the reputation is based on.

The examined Polish companies do not take up the activities aimed at continuous monitoring of submissions and comments about them either; they also do not use the tools enabling quick response to potential attacks. Therefore, reputation cannot be efficiently protected.

\section{$7 \quad$ References}

[1] Argenti, P.A., 2011. Digital strategies for powerful corporate communications. European Financial Review, vol. 79, February 17, pp.61-64.

[2] Buchnowska, D., 2013. Analysis and assessment of use of social media by the largest Polish companies. Business Informatics, 4(30), p.55-69.
[3] Connect, 2012. Social Enterprise 2012 report. [online] Available at: http:// www.socialenterprise.pl/raport [Acessed 17 May 2016].

[4] Czekańska-Mirek, B., 2011. O potrzebie rozwijania kompetencji komunikacyjnej u absolwentów pokolenia Y (The Need to Develop Communicative Competence at the Graduate Y Generation). In: K. Jędralska ed., J., Bernais, 2011. Kompetencje absolwentów studiów ekonomicznych. Perspektywa nauki Ibiznesu (Competence Graduate Studies. The Prospect of Science and Business). Katowice: Wydawnictwo Uniwersytetu Ekonomicznego w Katowicach, pp.163-170.

[5] Deloitte, 2012. Biznes społecznościowy - nowa era $w$ komunikacji biznesowej (Social Business - A New Era in Business Communication). [online] Available at: https:// marketingowe.files.wordpress.com/2013/10/ra port-biznes-spolecznosciowy.pdf [Accessed 17 July 2015].

[6] Distaso, M.W., McCorkindale, T., 2013. A Benchmark Analysis of the Strategic Use of Social Media for Fortune's Most Admired U.S. Companies on Facebook, Twitter and You Tube. Public Relations Journal, 7(1), pp.2-33.

[7] Edelman Trust Barometer: Executive Summary, 2015. [online] Available at: http://www.edelman.com/insights/intellectualproperty/2015-edelman-trust-barometer/trustand-innovation-edelman-trust-barometer/exe cutive-summary/ [Accessed 15 April 2016].

[8] Etter, M., 2013. Reasons for Low Levels of Interactivity: (Non-) interactive CSR Communication in Twitter. Public Relations Review, 39(5), pp.606-608.

[9] Filiciak, M., Danielewicz, M., Halawa, M., Mazurek, P., Nowotny A., 2010. Młodzi i media. Nowe media a uczestnictwo $w$ kulturze (Young and Media. New Media and Participation in Culture). Warszawa: SWPS. [online] Available at: http://bi.gazeta.pl/im/6/7600/m 7600446.pdf [Accessed 15 May 2016]. 
[10] Gonzalález-Herrero, A., Smith, S., 2008. Crisis Communications Management on the Web: how Internet-based Technologies are Changing the Way Public Relations Professional Handle Business Crises. Journal of Contingencies and Crisis Management, 16(3), pp.143-153, DOI: 10.1111/j.1468-5973.2008. 00543.x

[11] Kaplan, A., Haenlein, M., 2010. Users of the World, Unite! The challenges and Opportunities of Social Media. Business Horizons, 53(1), pp.59-68, DOI: 10.1016/j.bushor.20 09.09.003

[12] Kaznowski, D., 2010. Podziat i klasyfikacja social media (Division and Classification of Social Media). [online] Available at: http://networkeddigital.com/2010/05/10/podzi al-i-klasyfikacja-social-media/ [Accessed 24 June 2016].

[13] Królewski, J., Sala., P., 2014. E-Marketing. Wspótczesne trendy. Pakiet startowy (EMarketing. Contemporary Trends. Starter Pack). Warszawa: Wydawnictwo Naukowe PWN.

[14] Lariscy, R.W., Avery, E.J., Sweetser, K.D., Howes, P., 2009. Monitoring Public Opinion in Cyberspace: How Corporate Public Relations is Facing the Challenge. Public Relations Journal, 3(4), pp.1-17.

[15] Li, C., Bernoff J., 2011. Groundswell: Winning in the World Transformed by Social Technologies. Cambridge: Harvard Business Press.

[16] McAfee, A., 2009. Enterprise 2.0. New Collaborative Tools for Your Organization's Toughest Challenges. Boston: Harvard Business School Publishing.

[17] Mei, J., Bansal, N., Pang, A., 2010. New Media: A New Medium in Escalating Crises? Corporate Communications: An International Journal, 15(2), 143-155, DOI:

http://dx.doi.org/10.1108/13563281011037919

[18] Moroz, M., 2013. Efekty budowania wizerunku marki poprzez serwisy spolecznościowe - badanie opinii internautów pokolenia Y (The Effects of Building the Brand through Social
Networking Sites - Survey of Internet Generation Y). In: J. Gołuchowski ed., A. Frąckiewicz-Wronka, 2013. Wykorzystanie nowych mediów w Public Relations (The Use of New Media in Public Relations). Zeszyty Naukowe Wydziałowe Studia Ekonomiczne, seria 157, Katowice: Wydawnictwo Uniwersytetu Ekonomicznego w Katowicach.

[19] SocialMediaExaminer, 2013. Social Media Marketing Industry Report 2013. [online] Available at: https://www.socialmediaexami ner.com/SocialMediaMarketingIndustryReport 2013.pdf [Accessed 22 May 2016].

[20] Solis, B., 2011. Engage!: The Complete Guide for Brands and Businesses to Build, Cultivate and Measure Success in the New Web. Revised and Updated. Hoboken, New Jersey: John Wiley \& Sons. Inc.

[21] Sotrender, 2012. Polski Facebook 2012. [online] Available at: http://www.marketingnews.pl/photos/upd/130130123654_info552_1 arge.jpg [Accessed 22 May 2016].

[22] Sumara, K., Krzycki, M., Prokurat, S., Kubisiak, P ., 2012. Polskie firmy w mediach społecznościowych. Raport $\mathrm{z}$ badania (Polish Companies in Social Media. Research Report). Harvard Business Review Polska, No. 110, April 2012.

[23] Szamrowski, P., Pawlewicz, A., 2015. Wykorzystanie mediów społecznościowych w komunikacji $\mathrm{z}$ klientem na przykładzie firm sektora piwowarskiego (The Use of Social Media in Communication with the Customer on the Example of Companies Brewing Industry). Ekonomika i Organizacja Gospodarki Żywnościowej, No. 111, pp.161-176.

[24] Szczepańczyk, M., 2013. Innowacyjne sposoby wykorzystania mediów spolecznościowych $w$ komunikacji wewnętrznej i zewnętrznej organizacji (Innovative Ways of Using Social Media in Internal Communications and External Organizations). In: J. Gołuchowski ed., A. Frąckiewicz-Wronka, 2013. Wykorzystanie nowych mediów w Public Relations (The Use of New Media in Public Relations), Zeszyty Naukowe Wydziałowe Studia Ekonomiczne, 
seria 157, Katowice: Wydawnictwo Uniwersytetu Ekonomicznego w Katowicach.

[25] Weber Shandwick, 2009. Risky business. Reputation online. [online] Available at: http://www.webershandwick.de/download/086 00_Risky_WhitePaper_A4_FINAL.pdf [Accessed25 July 2015].

[26] Yang, S.U., Lim, J.S., 2009. The Effects of Blog-Mediated Public Relations (BMPR) on Relational Trust. Journal of Public Relations Research, 1(3), pp.341-359. DOI: 10.1080/10627260802640773

[27] www 1, 2011. Adidas przeprasza za mur na Stużewcu i rezygnuje z reklamy (Adidas apologizes for wall Stużewiec and gives up advertising). [online] Available at: http://tvn24 bis.pl/wiadomosci-gospodarcze, 71/adidas-prze prasza-za-mur-na-sluzewcu-i-rezygnuje-z-rek lamy, 166126.htm [Accessed 15 April 2016].

[28] www 2, 2010. Reklama sieci Play - psy w schronisku $i$ hasto "Zawsze możesz się go pozbyć" (Advertising Network Play - Dogs in the Shelter and the Slogan "You can always get rid of it". [online] Available at:

http://wiadomosci.gazeta.pl/wiadomosci/1,130 438,7936224, Reklama_sieci_Play_psy_w _schronisku_i_haslo_Zawsze.html [Accessed 15 April 2016].
[29] www 3, 2013. Social Networking Reaches Nearly One in Four Around the World. [online] Available at: https://www. emarketer.com/Article/Social-Networking-Rea ches-Nearly-One-Four-Around-World/100997 6\#sthash.gVa54X4n.dpuf [Accessed 17 May 2015].

[30] www 4, 2014. The Growth of Social Media in 2014: 40+ Surprising Stats [Infographic]. [online] Available at: http://www.shortst ack.com/the-growth-of-social-media-in-201440-surprising-stats-infographic/ [Accessed 17 May 2015].

[31] www 5, 2016, Polskie firmy rzadko korzystaja z mediów spolecznościowych (Polish Companies Rarely Benefit from Social Media). [online] Available at: http://www. forbes.pl /malo-korzystamy-z-mediow-spolecznosciowy ch-polskie-firmy-w-ogonie-ue, artykuly,20366 9,1,1.html [Accessed 25 March2016].

[32] www 6, 2016. Z Facebooka korzysta już 14 milionów Polaków (With Facebook Already Uses 14 Million Poles). [online] Available at: http://www.chip.pl/news/wydarzenia/trendy/2 016/03/z-facebooka-korzysta-juz-14-milionow -polakow [Accessed 17 May 2016]. 